\title{
A CONSTRUÇÃO POLÍTICA DO TERRITÓRIO CENTRO-SUL DA AMÉRICA PORTUGUESA (1668-1777)
}

\author{
MARIA DE FÁTIMA GOUVÊA \\ Universidade Federal Fluminense \\ MARIA FERNANDA BICALHO \\ Universidade Federal Fluminense
}

\section{RESUMO}

O artigo se propõe a investigar a crescente centralidade da cidade e da capitania do Rio de Janeiro no interior da região centro-sul da América portuguesa no período compreendido entre 1668 e 1777. Nesse sentido, optou-se por analisar três conjunturas sucessivas como estratégia para melhor compreender o processo de construção política do território, marcado por profundas confluências entre dinâmicas locais, regionais e imperiais.
PALAVRAS-CHAVE: América portuguesa; capitania do Rio de Janeiro; Brasil colônia.

\section{ABSTRACT}

The purpose of this article is to inquire about the key position of Rio de Janeiro captaincy in Central and Southern Portuguese America over the effective occupied territory, from 1668 to 1777. To achieve this goal, three main chronologies were selected to identify the political construction of the territory where local, regional and imperial dynamics deeply converged.
KEYWORDS: Portuguese America; captaincy of Rio de Janeiro; Colonial Brazil. 
"Eu o Príncipe como Regente e governador do Reino de Portugal e Algarves, faço saber a vós D. Manuel Lobo, fidalgo de minha casa, a quem tenho nomeado por Governador do Rio de Janeiro que dando me conta Alexandre de Sousa Freire, quando Governou o Estado do Brasil, e João da Silva de Sousa governador que também foi do Rio de Janeiro pelos ano de 1669 e 1671 enviando vários papeis e informações sobre se acharem de Povoar as terras do meu domínio que se acham ermas na demarcação da Repartição do Sul do mesmo estado que continuavam pelo Rio de Parta e Buenos Aires e o Montevidio pela fertilidade delas, com que já os Castelhanos têm feito varias colonias no territorio das que pertencem a esta Coroa, e ... mandando ver tudo por Ministros do Conselho de Estado e outras pessoas particulares depois de varias conferencias, informações e pareceres que se me fizeram presentes Houve por bem resolver que as ditas terras se povoem ...

Fui servido que fosseis pôr em execução esta nova Colonia no que vos haveis como vos ordeno, e mando por esta minha intrução."Regimento de 18 de novembro de $1678^{1}$.

A promulgação por D. Pedro, em fins de 1678, das instruções e regimento para fundação da Colônia de Sacramento antecipou o regimento passado pelo mesmo príncipe, a 7 de Janeiro de 1679, ao novo governador nomeado para o Rio de Janeiro, D. Manuel Lobo, a quem aquelas instruções foram dirigidas.2 Isso traduz com clareza a determinação do regente em mobilizar recursos régios, humanos e materiais para a realização de tamanha empreitada.

Várias são as questões que podem ser discutidas, tendo como base esses dois regimentos e o contexto no qual foram produzidos, para o estudo da construção política do território meridional da América portuguesa. Antes de mais nada, é preciso destacar a determinação do poder régio em levar a cabo a ocupação física do território, chamando a si o papel de orientar e conduzir mesmo que precariamente e apenas em termos de seus recursos jurídicoinstitucionais - o processo de construção territorial da porção sul do Brasil colonial.

1 Regimento editado em Lisboa em 18 de novembro de 1678. Cf. MENDONÇA, Marcos Carneiro (org.), Século XVIII. Século Pombalino no Brasil (1). Rio de Janeiro: Xerox do Brasil, 1989, p.29, apud MENDONÇA, Marcos Carneiro de (org.), Raízes da formação administrativa do Brasil (2), Tomo II, Rio de Janeiro, IHGB - Conselho Federal de Cultura, 1972. Há que se destacar, entretanto, o fato de que a versão aqui citada do regimento é diversa - tanto em termos de redação, quanto do idioma utilizado (português, ao invés do castelhano no original) - do referido na publicação do autor supra citada; ver p. 877-910 e 911-926.

2 Ibidem, p. 897, 911. 
Em segundo lugar, impõe-se chamar atenção para a posição central ocupada pela capitania do Rio de Janeiro no empreendimento de territorialização de uma imensa área que se encontrava ainda por ser efetivamente ocupada. Como se verá adiante, tanto as informações que o viabilizaram, quanto os recursos humanos e materiais que tornaram possível sua realização, foram disponibilizados por grupos do recôncavo da Guanabara, interessados e envolvidos num investimento político e econômico de grandes dimensões.

A praça do Rio de Janeiro constituía-se, desde meados do século XVI, sob o signo da profunda e curiosa confluência de interesses régios, reinóis e de grupos que, instalados na América portuguesa, deslocavam-se, pouco a pouco, para suas franjas e regiões meridionais. A criação da capitania real do Rio de Janeiro em 1567, e a divisão do Brasil em duas grandes circunscrições territoriais e administrativas (1571/1572) sinalizaram as fundações embrionárias desse processo. A citação extraída do regimento de 18 de novembro de 1678 aponta para uma terceira linha de reflexão, ao demarcar a confluência de interesses reinóis e ultramarinos, motor essencial da construção das múltiplas sociedades coloniais no Estado do Brasil. Confluência na qual o Rio de Janeiro desempenhou uma centralidade extraordinária na ocupação humana e material das regiões central e meridional.

Cabe, de antemão, destacar que a natureza do poder régio caracterizava-se, de acordo com a historiografia sobre o período, por sua posição de vanguarda na defesa da fé cristã, associada à expansão econômica, tanto na Europa, quanto em suas conquistas ultramarinas. A coroa, como cabeça de uma monarquia corporativa, capaz de reconhecer os poderes locais instituídos - e a ela vinculados -, desempenhava uma centralidade essencial no que dizia respeito à confirmação de prerrogativas, direitos e posições de indivíduos e grupos nas hierarquias sociais que configuravam a monarquia portuguesa na época moderna ${ }^{3}$. No que se refere ao ultramar, a coroa conservava sua posição estratégica ao proceder ao recrutamento e às nomeações, ao conferir regimentos a oficiais régios que davam forma ao aparato político-administrativo que progressivamente se instituía sobre 0 conjunto de seus domínios ultramarinos. ${ }^{4}$ Nesse sentido, o estudo da construção política do território do Estado do Brasil evoca, por um lado, a compreensão do processo simultâneo de construção da autoridade régia sobre o espaço meridional da América portuguesa. $E$, por outro, a percepção de que a coroa sempre dispôs, in loco, de poderosos aliados, tanto em termos sociais, quanto político-econômicos; recursos humanos e materiais que foram

3 HESPANHA, António Manuel. As vésperas do Leviathãn. Instituições e Poder Político em Portugal. Coimbra: Editora Almedina, 1994.

4 MONTEIRO, Nuno Gonçalo. Trajetórias sociais e governo das conquistas. Notas preliminares sobre os vice-reis e governadores-gerais do Brasil e da Índia nos séculos XVII e XVIII. In João Luís FRAGOSO, Maria de Fátima Gouvêa, Maria Fernanda Bicalho (orgs.), O Antigo Regime nos Trópicos. A dinâmica imperial portuguesa, sécs. XVI-XVIII. Rio de Janeiro: Civilização Brasileira, 2001, p. 249-283. 
recorrentemente mobilizados, de acordo com as diferentes conjunturas, como se verá adiante.

Há que acrescentar, no entanto, um elemento singularizador da região aqui tratada. O rio da Prata desempenhou desde sempre um impulso magnetizador, capaz de atrair uma grande diversidade de recursos humanos e materiais, na medida em que possibilitava sua vinculação a interesses e regiões sob o domínio de Castela. O El Dorado capaz de fazer com que Martim Afonso de Sousa - antes de partir para o Oriente - enfrentasse a dificil tarefa de navegar na embocadura do seu estuário durante a realização das primeiras expedições portuguesas de reconhecimento e conquista do litoral do Brasil na década de 1530. Embora tivesse sobrevivido ao naufrágio de sua embarcação, perdeu vários homens de sua expedição, inclusive seu próprio irmão, Pero Lopes de Sousa.

Optou-se aqui por trabalhar com três principais faixas cronológicas como estratégia para melhor caracterizar o processo de construção política do território, marcado pela profunda confluência entre dinâmicas locais, regionais e reinóis.

A primeira conjuntura, de 1668 a 1720, é marcada no centro político do Império pela regência e reinado de $D$. Pedro II, assim como pelos primeiros anos do reinado de D. João V. No Brasil, e na região centro-sul que aqui nos interessa, destacaram-se nesta conjuntura a importância do eixo comercial Rio de Janeiro - Luanda - Rio da Prata; o regimento de D. Manuel Lobo, nomeado governador do Rio de Janeiro em 1679, a instrução que recebia para erigir um porto fortificado naquele estuário e a decorrente fundação da Colónia do Sacramento em 1680. Igualmente relevante para o estatuto de centralidade da capitania e da cidade do Rio de Janeiro, embora anterior à conjuntura aqui privilegiada, foi a instituição, em fins de 1572, da Repartição Sul, englobando as capitanias do Rio de Janeiro, São Vicente e Esprírito Santo, sob a jurisdição do governo da primeira. A Repartição-Sul permaneceu demarcada e independente do Governo-Geral na Bahia até o ano de 1612, sendo reinstituída entre 1643-1658 e, novamente, em 1679, já sob o governo de D. Manuel Lobo. Em 1674, apenas seis anos antes da fundação da Colónia do Sacramento, D. Pedro doou as terras que se estendiam de Laguna (Santa Catarina) ao Rio da Prata ao Visconde de Asseca e a João Correa de Sá. Em 1676 foi criado o bispado do Rio de Janeiro, com jurisdição sobre toda a região sul. Em 1689 D. Pedro II determinava que cabia aos governadores do Rio prover postos militares e das ordenanças; em 1693 conferia-Ihes ampla jurisdição em tudo o que se referisse às minas recém-descobertas, podendo criar povoações e darIhes regimentos pelos quais se governassem, política, civil e judicialmente. Artur de Sá e Meneses, nomeado em 1697, foi o primeiro governador do Rio com patente de capitão general. No mesmo ano foi-lhe concedida jurisdição sobre as minas, sem outra subordinação que ao próprio rei. Em 1698 a capitania de São Paulo subordinou-se ao governo do Rio de Janeiro. Em 1699 a Colônia do Sacramento sujeitou-se ao mesmo governo.

A segunda conjuntura, de 1720 a 1750, é marcada pelo povoamento e fundação de estabelecimentos portugueses tanto no sul, quanto no centrooeste do Brasil, destacando-se, em 1723, o projeto, embora falhado, de criação 
de uma povoação em Montevidéu, no estuário do Prata. Em 1720 é criada a capitania de Minas (sendo desmembrada da de São Paulo), cujo governo, a partir de 1735, ficará sob a jurisdição do governador do Rio de Janeiro, que na época - até 1763 - era Gomes Freire de Andrade. A década de 1720 destacouse também pela abertura de uma rede de caminhos ligando os territórios do sul, desde a Colônia do Sacramento, a São Paulo e Rio de Janeiro. Entre 1735 e 1737 a Colónia sofreu um grande cerco por parte de forças espanholas provenientes de Buenos Aires. $\mathrm{O}$ ano de 1737 marca o estabelecimento mais sistemático da administração portuguesa no território do Rio Grande de São Pedro. José da Silva Paes, então governador interino do Rio - durante a permanência de Gomes Freire nas Minas - foi nomeado comandante de terra, com a instrução ocupar e fortificar o Rio Grande, tomar Montevidéu, e preparar uma terceira expedição de socorro à Colônia. Terminado o cerco espanhol à Colônia, parte das forças remetidas em sua defesa foram distribuídas pelo Rio Grande, Santa Catarina, ou voltaram ao Rio, além das que ficaram naquela praça. A partir de então iniciar-se-ia a colonização mais intensiva do Rio Grande e de Santa Catarina, abrindo-se novas estradas e caminhos pelos seus sertões. Em 1738 a Ilha de Santa Catarina e o Rio Grande de São Pedro foram subordinados ao governo do Rio de Janeiro. Em 1740 Laguna foi retirada da jurisdição de São Paulo, e incorporada à do Rio. Saindo um pouco do âmbito geográfico desta investigação, em 1748 foram criadas as capitanias de Goiás e de Mato Grosso, cujos territórios, desmembrados da jurisdição de São Paulo, passaram a ser governados interinamente por Gomes Freire de Andrade.

A terceira conjuntura, de 1750 a 1777, inicia-se com a criação, em 1751, do Tribunal da Relação do Rio de Janeiro, o que viria, em vez de enfraquecer, dilatar em diferentes campos, a jurisdição do governador daquela capitania. Seus primeiros anos foram marcados pelas negociações em torno do cumprimento do Tratado de Madrid, que deslocaram Gomes Freire de Andrade para o sul, a fim de supervisionar os trabalhos de demarcação ali desenvolvidos. Quando ainda se encontrava no sul, eclodia, na Europa, a Guerra dos Sete Anos, que viria a ter consequências funestas nas franjas meridionais entre os domínios portugueses e castelhanos na América. D. Pedro de Cevallos, governador de Buenos Aires, planejou um ataque aos fortes portugueses naquela região com a finalidade de expulsá-los não só da Colônia, mas também do Rio Grande e de Santa Catarina. Em agosto de 1762 transportou homens para as cercanias da Colônia, expulsando os portugueses e tomando a cidadela entre outubro e novembro. Em abril de 1763, arregimentou cerca de 1.000 homens, conduzindo-os até as muralhas das fortalezas lusas de Santa Teresa e São Miguel, a sul da Lagoa Mirim. Nova vitória dos castelhanos. De posse daquelas fortalezas, as tropas castelhanas tinham caminho aberto para a vila do Rio Grande, onde de fato entraram em abril de 1763. Rumavam já os espanhóis para Viamão, quando receberam notícias da suspensão das rivalidades na Europa. Foi nesse contexto político internacional, no ano de 1763, que ocorreu a transferência da sede do vice-reinado doBrasil de Salvador para o Rio de Janeiro, movimento que coroou sua indiscutível centralidade. Em 
1776 recrudesceriam as disputas luso-espanholas naquela região. Em fevereiro de 1777 uma grande expedição saída de Cádiz, capitaneada pelo Marquês de Casa Tilly e por D. Pedro de Cevallos, tomava a ilha de Santa Catarina. O próximo passo foi a conquista definitiva da Colônia do Sacramento e a total destruição da cidadela. No reino falecia D. José I e o Marquês de Pombal perdia seu protagonismo político. Em outubro de 1777 foi assinado o Tratado de Santo Idelfonso, de acordo com o qual caberia à Espanha a área da Colônia do Sacramento, embora Portugal continuasse a manter o Rio Grande e toda a região das lagoas Mirim e dos Patos, até Santa Catarina.

\section{Primeira conjuntura: 1668-1720}

A criação da capitania real do Rio de Janeiro pelo governador-geral Mem de Sá, a 4 de Março de 1567, selou um período de intensas disputas travadas entre portugueses, populações nativas locais, corsários e calvinistas franceses que haviam se estabelecido no recôncavo da Guanabara 5 . O esforço capitaneado por Mem de Sá - que havia custado a vida de seu sobrinho, Estácio de Sá, fundador da cidade de São Sebastião do Rio de Janeiro traduziu a importância que as autoridades régias dedicavam, já àquela altura, à região da Guanabara. Ponto estratégico na navegação da costa do Brasil, o porto do Rio de Janeiro surgia como eixo de essencial importância na conexão entre o litoral norte/nordeste e as regiões mais a sul de São Vicente. Sua localização viabilizava a incursão de grupos e interesses portugueses ao estuário do rio da Prata, estabelecendo contatos - tanto por mar, quanto por terra - com a extensa região mercantil que envolvia as minas de prata de Potosi, no Alto Peru.

É possível perceber a forma como o Rio de Janeiro - cidade e capitania - nasciam, em termos geográficos e institucionais, sob o signo da conexão norte e sul daquilo que ia, pouco a pouco, se tornando o Brasil. Segundo C. R. Boxer e Luiz Felipe de Alencastro, sua posição meridional permitiu aos interesses comerciais nelas enraizados condições excepcionais de trânsito entre as possessões espanholas conectadas pelo rio da Prata e os enclaves portugueses e negreiros na África. Durante a união das coroas ibéricas (1581-

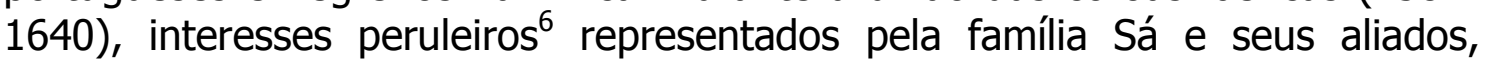
tinham acesso privilegiado aos portos e territórios banhados por aquele estuário. Salvador Correia de Sá e Benevides, inúmeras vezes governador do Rio de Janeiro (de 1637 a 1643; novamente em 1648 e, por último, entre 1658

5 KNAUSS, Paulo. $O$ Rio de Janeiro da pacificação. Franceses e portugueses na disputa colonial. Rio de Janeiro: Prefeitura da Cidade do Rio de Janeiro, 1991; BICALHO, Maria Fernanda. $A$ Cidade e o Império. O Rio de Janeiro no século XVIII. Rio de Janeiro: Civilização Brasileira, 2001.

6 Peruleiros: substantivo de origem espanhola usado no começo do século XVII para designar os comerciantes da América portuguesa que faziam negócios com os espanhóis do Baixo Peru e, mais concretamente, importavam prata da região platina. ALENCASTRO, Luiz Felipe de. $O$ trato dos viventes. Formação do Brasil no Atlântico sul. São Paulo: Companhia das Letras, 2000, p. 110 . 
e 1661), comandante da armada que em 1648 reconquistaria Angola aos holandeses, e membro do Conselho Ultramarino, foi um dos responsáveis pela montagem do triângulo comercial Rio de Janeiro-Luanda-Buenos Aires. Na década de 1640, lembrava Salvador de Sá a D. João IV a conveniência da colonização das terras a sul de São Vicente. ${ }^{7}$

A jurisdição sobre o território meridional da América portuguesa e sua condição nos quadros da administração colonial sofreu inúmeras modificações ao longo dos séculos XVII e XVIII. Em carta régia de 17 de junho de 1674, o regente D. Pedro doou as terras que se estendiam de Laguna (Santa Catarina) ao Rio da Prata ao Visconde de Asseca e a João Correa de Sá. ${ }^{8}$ Em1676 foi criado o bispado do Rio de Janeiro, com jurisdição sobre toda a região sul, sendo o da Bahia alçado à posição de arcebispado ${ }^{9}$. Em 1678, e ainda em 1679, os regimentos acima citados, conferidos por D. Pedro a D. Maunel Lobo, traduziam a determinação do príncipe regente em tomar posse e estender seus domínios até a embocadura do Prata. Em 1680 foi fundada, por aquele governador, a Colónia do Sacramento. ${ }^{10}$

Os primeiros governadores do Rio de Janeiro, desde Salvador Correa de Sá (1568), foram investidos com a patente de capitão mor, e eram sujeitos ao governador-geral na Bahia. Passaram-se apenas cinco anos para que a coroa criasse, em fins de 1572, a repartição sul, englobando as capitanias do Rio, São Vicente e Espírito Santo, avançando mais significativamente na afirmação do estatuto de centralidade da primeira, cujo governo exerceu jurisdição sobre as demais até $1612 .{ }^{11}$ A recriação da repartição sul, na década de 1630 , sob a

7 BOXER, C. R. Salvador de Sá e a luta pelo Brasil e Angola, 1602-1686. São Paulo: Companhia Editora Nacional / Editora de Universidade de São Paulo, 1973.

8 FREIRE, Felisbello. História da Cidade do Rio de Janeiro. vol. I (1564-1700). Rio de Janeiro: Typ. da Revista dos Tribunais, 1912. Como não tomaram posse, aquelas terras voltaram ao património da coroa em 1727.

9 Nessa ocasião foi igualmente estabelecido o bispado de Olinda, sendo que dois anos depois foram criados os bispados de Angola e Congo, e o do Maranhão. Cf. GOUVÊA, Maria de Fátima S. Poder político e administração na formação do complexo atlântico português (1645-1808). In FRAGOSO, J.; GOUVÊA, M. F. S.; BICALHO, M. F.. Op. Cit., p. 285-315.

10 Sobre a Colônia do Sacramento, cf. ALMEIDA, Luis Ferrand. A Colônia do Sacramento na Época da Sucessão de Espanha. Coimbra: Faculdade de Letras da Universidade de Coimbra, 1973; PRADO, Fabrício P. Colônia do Sacramento. O extremo-sul da América portuguesa. Porto Alegre: F. P. Prado, 2002; POSSAMAI, Paulo César. $A$ vida cotidiana na Colónia do Sacramento. Um bastião português em terras do futuro Uruguai. Lisboa: Editora Livros do Brasil, 2006.

11 Segundo F. Freire, os motivos que inspiraram à coroa este ato, encontram-se na carta de nomeação do governador-geral das capitanias do norte, Luís de Brito de Almeida, de 10 de Dezembro de 1572, na qual D. Sebastião afirma que: "Considerando eu como por as terras da costa do Brasil serem tão grandes e tão distantes umas das outras e haver já agora nelas muitas povoações e esperança de se fazerem muitas mais pelo tempo em diante, não podiam ser tão inteiramente governadas como cumpria por um só governador, como até aqui nelas houve, assentei assim para o que convém à conversão do gentio daquelas partes e se dilatar nelas nossa santa fé, como para mais brevemente se administrar a justiça e a elas se poderem melhor defender e por outros respeitos de mandar dois governadores às ditas partes um para residir na cidade do Salvador da capitania da Baía de Todos-os-Santos, e outro na cidade de São Sebastião do Rio de Janeiro, para governar cada um deles as terras de seus limites, conforme a repartição que para isso mandei fazer". Por alvará régio de 9 de Abril de 1612, as 
administração de Salvador de Sá e Benevides, conferiu a este governador, pela primeira vez, a patente de mestre-de-campo, herdada, desde então, por aqueles que o sucederam. ${ }^{12}$ Ao reassumir o governo em 1658, Salvador Correia de Sá e Benevides seria mais uma vez nomeado governador das capitanias do sul. Instituto político-administrativo que, embora em parte conferido como mercê pelos inúmeros serviços prestados por Salvador de Sá à nascente dinastia dos Bragança, foi utilizado em termos jurisdicionais pela coroa portuguesa no sentido de reafirmar a importância do Rio de Janeiro frente às demais circunscrições administrativas do Estado do Brasil. Quando deixou de ser governador, a capitania do Rio de Janeiro, assim como as de São Vicente e de São Paulo, voltaram a subordinar-se ao governo-geral na Bahia e, a 10 de outubro de 1663, um regimento baixado na administração do Conde de Óbidos, segundo vice-rei do Estado do Brasil, restringiu significativamente as competências dos governadores do Rio. ${ }^{13}$

A partir do governo de D. Manuel Lobo, e da fundação da Colónia do Sacramento, os seus poderes foram novamente ampliados, como demonstram as instruções e regimentos citados no início deste capítulo. De acordo com a provisão de 12 de Novembro de 1679, as capitanias do sul voltaram a depender da jurisdição do Rio de Janeiro, mais uma vez autónoma em relação à Bahia. A

capitanias do Rio de Janeiro, São Vicente e Espírito Santo foram novamente reunidas ao governo-geral na Bahia. FREIRE. Op.Cit., vol. I, p. 56 e 109. Cf. também RIBEIRO, Mônica da Silva. Divisão governativa do Estado do Brasil e a Repartição do Sul (1). Usos do Passado - XII Encontro Regional de História ANPUH-Rio, 2006, Niterói. Disponível em:

(http://www.rj.anpuh.org/Anais/2006/conferencias/Monica\%20da\%20Silva\%20Ribeiro.pdf).

12 Em 1639, Salvador Correia de Sá e Benevides foi autorizado a ingerir-se nos negócios da guerra, justiça e fazenda das capitanias do Rio de Janeiro, São Vicente e São Paulo, cabendoIhe também perdoar os criminosos dos sertões daquelas circunscrições administrativas. Em provisão de 9 de Março de 1641, o Marquês de Montalvão, primeiro governador-geral do Brasil com o título de vice-rei, alegava que, "S.M. foi servido fazer mercê a Salvador Corrêa de Sá e Benevides, por outros serviços que Ihe havia feito, de cargo de governador do Rio de Janeiro, concedendo-lhe que usasse de todos os poderes, jurisdição e alçada que tiveram e de que usaram os capitães-mores e governadores daquela capitania, seus antecessores (...); e outrossim lhe fez mercê de que usasse o soldo de mestre de campo e que tivesse a administração das minas de São Paulo (...)". Em Março de 1644, Salvador de Sá foi nomeado General das Frotas do Brasil e, em Junho do mesmo ano, Governador da exploração das minas. No entanto, segundo F. Freire, que cita a referida provisão, afirma que enquanto Salvador de Sá esteve no governo, suas atribuições foram mantidas, não as podendo usar, no entanto, seus sucessores, que só herdaram a patente de mestre de campo, e não mais a de capitães mores. FREIRE. Op.Cit., p. 299-300. Cf. também BOXER. Op.Cit., caps. 4 e 5.

13 F. Freire afirma que ao reassumir o governo do Rio de Janeiro, Salvador de Sá e Benevides foi nomeado, por carta régia de 17 de Setembro de 1658, governador das capitanias do sul, sem dependência do governador e capitão general da Bahia. A 10 de Outubro de 1663, o Rio de Janeiro voltou à jurisdição do governo-geral, recebendo seu governador, um novo regimento que, ao reafirmar a competência militar de seu ofício, cabendo-lhe propor pessoal idóneo para preencher as vagas da infantaria paga, das Ordenanças ou Auxiliares, restringia suas prerrogativas no campo da justiça e da fazenda. Nestas duas esferas restringia-se a propor nomes, podendo prover o cargo interinamente durante seis meses. Proibia-se-lhe, no entanto, que se intrometesse nos negócios a cargo do provedor da fazenda, e ainda nos assuntos relativos à justiça e à câmara. Não poderia dar sesmarias, senão informar as petições. No caso de prender alguma pessoa, nenhuma outra autoridade poderia revogar a sua ordem. FREIRE. Op.Cit., p. 300-301. 
carta régia de 2 de março de 1689 determinou que cabia aos seus governadores prover postos militares e das ordenanças. A 14 de janeiro de 1693, a Coroa conferia-Ihes ampla jurisdição em tudo o que se referisse às minas recém-descobertas. ${ }^{14} \mathrm{O}$ alvará de 27 de dezembro do mesmo ano, outorgava-Ihes alargados poderes em relação à defesa da capitania, podendo criar povoações e dar-Ihes regimentos pelos quais se governassem política, civil e judicialmente. Artur de Sá e Meneses, nomeado a 12 de janeiro de 1697, foi o primeiro governador com patente de capitão general. No mesmo ano, a 27 de dezembro, foi-lhe concedida jurisdição sobre as minas, sem outra subordinação além de ao próprio rei. Em Novembro de 1698, a capitania de São Paulo subordinou-se ao governo do Rio de Janeiro, salvo em competências da justiça, que continuavam sob a alçada do Tribunal da Relação da Bahia. Um ano depois, em novembro de 1699, foi a vez da Colônia do Sacramento sujeitar-se ao Rio de Janeiro. Segundo Felisbello Freire, antigo historiador da cidade, no final do século XVII, "o Rio de Janeiro era a metrópole, a vida administrativa e política do Sul'. ${ }^{15}$ A carta régia de 10 de Dezembro de 1701 confirmaria, uma vez mais, que os territórios e capitanias do sul, incluindo São Vicente, São Paulo, Santos e as minas recém-descobertas permanecessem subordinados ao governo do Rio. ${ }^{16}$ Em novembro de 1709, porém, foi criada a capitania de São Paulo e Minas, cabendo sua administração a Antônio de Albuquerque Coelho de Carvalho.

Os últimos anos dos seiscentos iriam testemunhar a promessa de riquezas e uma outra força centrífuga atrairia o Rio de Janeiro em direcção ao sertão, sem, no entanto, ferir seu estatuto de praça comercial e marítima, conferindo-lhe, ao contrário, maior importância e centralidade na América portuguesa. A descoberta do ouro inauguraria um novo século e também uma nova fase, constituindo-se em marco fundador de um longo período de prosperidade, multiplicando os sentidos e alargando o raio das rotas percorridas por navios e expedições que transitavam a partir da e com destino à cidade do Rio de Janeiro. Seu porto constituir-se-ia a partir de então - e por todo o século XVIII - no principal receptor de escravos e mercadorias européias e asiáticas, assim como no maior escoador das riquezas coloniais, transformando-se, como

14 A vila de São Paulo de Piratininga, fundada em torno do Colégio dos Jesuítas, instalados no planalto paulista, em 1554, abria-se às rotas do sertão, constituindo-se, segundo Heloisa Bellotto, numa "zona de transição, entroncamento de caminhos. Galgada a serra, a penetração poderia ser feita, por São Paulo, para os campos do Sul, para as serranias mineiras e para o Oeste, sempre ao longo dos rios". Bellotto afirma ainda que após a Restauração, o bandeirismo de apresamento decaiu, entre outras razões, devido à crescente introdução de africanos. As atenções dos paulistas voltaram-se então, para a procura mais intensiva do ouro, o que levou ao achamento das minas de Cataguazes. A descoberta oficial do ouro data de 1693-1694, com os achados de António Rodrigues Arzão e de Bartolomeu Bueno de Siqueira. BELLOTTO, Heloísa L. Autoridade e Conflito no Brasil Colonial: o governo do Morgado de Mateus em São Paulo (1765-1775). $2^{\text {a }}$ ed. Revista. São Paulo: Alameda, 2007, p. 23-24.

15 FREIRE. Op.Cit., p. 303.

16 Segundo F. Freire, uma carta régia anterior, de 22 de novembro de 1698, sujeitava as terras do sul ao governo-geral da Bahia, ficando anexas ao governo do Rio de Janeiro. FREIRE. Op.Cit., vol. II, p. 408-409. 
já dizia António Rodrigues da Costa, conselheiro do Conselho Ultramarino, em "uma das pedras mais preciosas que ornam a coroa de Vossa Majestade, de cuja conservação e bom governo depende a segurança das Minas, e ainda de todo o Brasil'. 17

Por outro lado, desde a fundação da Colónia do Sacramento, a região meridional da América tornou-se alvo de intensa disputa, pontuada por incursões militares e negociações diplomáticas entre as monarquias ibéricas. Uma série de tratados assinados no contexto da Guerra de Sucessão - em 1701,1703 e 1715 - atribuiu legitimidade às pretensões lusas sobre aquele território. ${ }^{18}$ A adesão de Portugal à Grande Aliança motivou a invasão de Sacramento, em 1705, por forças castelhanas. Porém, compelida pelo Tratado de Utreque, a coroa espanhola foi obrigada a reconhecer o direito de soberania do rei de Portugal na cidadela platina. Sacramento foi novamente ocupada por luso-brasileiros em $1716 .{ }^{19}$ Seu território, no entanto, ficou restrito, pelo mesmo tratado, ao raio de um tiro de canhão, embora essa cláusula não viesse a ser respeitada. O período entre 1716 e 1735 foi marcado pela expansão e prosperidade de um entorno agrícola e pastoril da cidadela.

\section{Segunda conjuntura: 1720-1750}

Na década de 1720 vários projetos de ocupação dos territórios meridionais povoaram a correspondência dos governadores do Rio de Janeiro para a Coroa. Em carta ao Secretário de Estado, de 24 de janeiro de 1723, Aires de Saldanha e Albuquerque sugeria a ocupação da região de Montevideu, uma vez que a Colónia do Sacramento possuía um entorno pastoril de cerca de 30 léguas. Em resposta, recebeu ordens de Lisboa para tomar posse do território. Imediatamente mandou preparar uma expedição de 150 homens que, ao chegar ao Rio da Prata, foi desbaratada por forças enviadas de Buenos Aires, seguindo-se, em 1724, a fundação de Montevideu pelos castelhanos. Luís Vahia Monteiro, sucessor de Aires de Saldanha, foi responsável pelas primeiras gestões para o povoamento do Rio Grande. Durante sua administração chegaram ao Rio de Janeiro, partindo para o sul e, posteriormente, para o Espírito Santo, São Paulo, Minas, Goiás e Mato Grosso, os padres matemáticos Diogo Soares e Domingos Capassi, encarregados do reconhecimento do território e da elaboração de um novo atlas do Brasil. ${ }^{20}$ No entanto, seria

17 Parecer de Antônio Rodrigues da Costa, Consulta do Conselho Ultramarino de 21 de abril de 1712. (AHU, RJ, Avulsos, Cx. 9, doc. 47). Cf. BICALHO, M. F. A Cidade e o Império. O Rio de Janeiro no século XVIII. Rio de Janeiro: Civilização Brasileira, 2001; SAMPAIO, A. C. Jucá de. Na Encruzilhada do Império. Rio de Janeiro: Arquivo Nacional, 2003.

$18 \mathrm{Em} 1701$ o pretendente francês ao trono espanhol ofereceu a Portugal, em troca de sua neutralidade na guerra, a posse incontestável da Colônia. Dois anos mais tarde, uma das cláusulas do Tratado de Methuen explicitava o compromisso da Inglaterra em assegurar aquelas terras sob o domínio de seu aliado.

19 Cf. ALDEN, Dauril. Royal Government in Colonial Brazil. Berkeley - Los Angeles: University of California Press, 1968.

20 Cf. ALMEIDA, André F. de. A formação do espaço brasileiro e o projeto do Novo Atlas da 
apenas na gestão de Gomes Freire de Andrade, e com o apoio técnico dos mesmos jesuítas, assim como do brigadeiro e engenheiro militar José da Silva Pais, que o território do Rio Grande de São Pedro seria ocupado, povoado e fortificado.

Gomes Freire governou o Rio de Janeiro de Julho de 1733 (sua carta patente é de 8 de Maio) até Janeiro de 1763, quando faleceu naquela cidade. A 2 de Janeiro de 1735 seria nomeado governador de Minas Gerais, acumulando - governo das duas capitanias, numa conjuntura delicada, marcada pelas negociações - intermediadas por Martinho de Mendonça de Pina e Proença para a implantação da capitação. ${ }^{21}$

Partindo Gomes Freire para as Minas, o governo do Rio foi entregue ao mestre de campo Matias Coelho de Sousa, até que chegasse o brigadeiro José da Silva Pais, nomeado governador interino por carta régia de 4 de janeiro de 1734. Durante a administração de Silva Pais novas hostilidades entre forças portuguesas e castelhanas eclodiram no sul. Antônio Pedro de Vasconcelos, governador da Colónia de Sacramento, insistia na necessidade de ligar aquela praça, por terra, a outras regiões sob o domínio português, sobretudo a Laguna. Por volta de 1726, ao mesmo tempo que João de Magalhães abria um caminho de Laguna ao Rio Grande, outra estrada era construída, a partir de Curitiba. Enquanto aqueles campos eram devassados, no ano de 1735, um incidente diplomático tornava melindrosas as relações entre Portugal e Espanha. ${ }^{22}$ Sem sabê-lo ainda, D. Miguel de Salcedo, governador de Buenos Aires, insistia na cláusula do Tratado de Utreque, de que o território da Colônia do Sacramento não ultrapassaria o raio de um tiro de canhão. A 26 de outubro, sem que se soubesse ao certo o que se passava entre Portugal e Espanha, chegaram ao Rio notícias o deflagrar aberto de hostilidades entre os governadores de Buenos Aires e o da Colônia, armando-se o grande sítio que esta sofreria nos dois anos seguintes (1735-1737). ${ }^{23}$

América Porutuguesa. Lisboa: CNCDP, 2001; BICALHO, M. F. Sertão de Estrelas. A delimitação das Latitudes e das Fronteiras na América Portuguesa. Varia Historia, vol. 21, julho (1999), p. 73-85.

21 Cf. CAVALCANTI, Irenilda R. B. R. M. O comissário real Martinho de Mendonça (169317430): Estratégias e práticas administrativas na primeira metade do século XVIII. Niterói: PPGH-UFF, 2010 (tese de doutorado inédita); COSTA, André da Silva. Direitos Reais, Tributação, Governo. Os 'papéis' sobre a capitação do ouro na dinâmica política da Corte (1731-1750). Texto inédito.

22 Segundo Jorge Borges de Macedo, em 1735 ocorreu um incidente entre Portugal e Espanha, relacionado com a prisão, em Madrid, de uns criados da embaixada portuguesa. Seguiu-se o corte de relações diplomáticas entre os dois países. MACEDO, J. B. de, História Diplomática Portuguesa. Constantes e linhas de força. Lisboa: Ed. da Revista Nação e Defesa", s. d., p. 271. A notícia do incidente diplomático chegou ao Rio de Janeiro, comunicando-a José da Silva Pais a Gomes Freire, que se encontrava ainda em Minas, em carta de 17 de junho de 1735. Em agosto, comunicou-a também ao governador da Colónia.

23 Silva Pais remeteu socorro de seis navios a Antônio Pedro de Vasconcelos, dois deles armados em guerra com 50 e 20 canhões, sob o comando do sargento-mor Tomás Gomes. A essa expedição deveriam unir-se duas corvetas que havia anteriormente expedido para Paranaguá, Cananéia e Laguna, com carga de farinhas. A expedição só chegou a Sacramento a 6 de janeiro de 1735, quando se soube que o sítio à Colônia começara em 10 de outubro do 
O ano de 1737 marca o estabelecimento mais sistemático da administração portuguesa no território do Rio Grande de São Pedro. A 12 de março de 1736 chegaram ordens de Lisboa para que Silva Paes partisse, ele próprio, para o sul, e para que Gomes Freire retornasse ao Rio de Janeiro. A expedição de Silva Pais saiu do Rio a 24 de junho de $1736 .{ }^{24}$ Levava instruções para desembarcar em Santa Catarina, onde juntar-se-ia aos paulistas que desciam por terra, comandados por Cristóvão Pereira; e esperaria reforços provenientes de Sacramento, que, devido à dificuldade em furar o cerco espanhol, acabaram por não chegar. Demorou-se mais do que o previsto naquele porto, e quando saiu, em início de Agosto de 1736, as embarcações de sua esquadra dispersaram-se devido às tormentas e à chegada de reforços enviados de Madri, frustrando o ataque a Montevidéu. Sem outra alternativa e coagido pelos espanhóis, Silva Pais rumou para o Rio Grande a fim de formar corpo de cavalaria para socorrer a Colónia. Instruções de Gomes Freire insistiam na necessidade de defesa de Santa Catarina. Celebrado, em 1737, o armistício entre Portugal e Espanha, Silva Pais recebeu ordens para voltar ao Rio de Janeiro, não sem antes entregar o governo do Rio Grande ao comandante do regimento de dragões que ali se criara. Terminado o cerco espanhol à Colônia, parte das forças remetidas em sua defesa foram distribuídas pelo Rio Grande, Santa Catarina, ou voltaram ao Rio, o que demonstra a fluidez dos efetivos militares no sul da América portuguesa. A partir de então iniciar-se-ia a colonização mais intensiva do Rio Grande e de Santa Catarina, abrindo-se estradas e caminhos pelos seus sertões. ${ }^{25}$

ano anterior. Segunda expedição foi preparada, composta de dois navios, o primeiro, comandado pelo capitão de mar e guerra Cipriano de Melo, com 250 homens; o segundo, com 18 peças e 160 homens, uma balandra com 12 peças e 50 homens, além de embarcações menores. Essa expedição, que saiu do Rio a 12 de março de 1736, com ordens de aportar em Maldonado, encaminhar-se pelo canal do sul e enseada de Barragã, com o intuito de atacar as embarcações espanholas, incendiá-las e impossibilitá-las de resistir, para que pudessem livremente desembarcar e se assenhorear da costa. Embora algumas náus inimigas tivessem sido incendiadas, e D. Miguel Salcedo recolhesse a infantaria e a artilharia de volta a Buenos Aires, deixou na campanha um corpo de 600 cavalos, duramente atacados pelos portugueses. No entanto, o bloqueio não foi suspenso, impondo ao governo de Lisboa, e ao do Rio de Janeiro, uma estratégia alternativa.

24 José da Silva Pais foi nomeado comandante de terra. Com ele partiram António Ribeiro, no posto de segundo coronel, e Luís de Abreu Prego como comandante da esquadra, constituída de 3 fragatas e 200 soldados, além de duas naus de comboio. Para futuro governador de Montevidéu, se a expedição chegasse a bom termo, fora indicado o mestre de campo André Ribeiro Coutinho, com ordens de formar uma companhia de dragões de 80 cavalos em pé, comandada pelo tenente dos dragões das Minas, Domingos da Luz, que já havia socorrido anteriormente a Colónia. Das Minas também saíram o furriel e o alferes dos dragões António José e Manoel Ferreira, para assumirem postos destacados na nova conquista. Pelo menos era isso que sugeria, em carta ao rei, Gomes Freire de Andrade. Afirmava que não nomearia imediatamente governador para o no Rio Grande, embora recomendasse a passagem de casais das ilhas para povoá-lo. Novo reforço vindo de Lisboa seria remetido em Setembro. Da Espanha saíra igualmente duas fragatas de 50 peças cada uma, com 300 dragões destinados a auxiliar 0 governador de Buenos Aires no assédio à Colónia. FREIRE. Op.Cit., p. 554-555.

25 Segundo Fabrício Prado, nos primeiros anos do século XVIII, quando a população de Sacramento já superava 1.500 almas, já havia um caminho ligando a Colónia ao Rio Grande. 0 governador Sebastião da Veiga Cabral incentivava a exploração da campanha com a agricultura e a produção de couros. A partir de 1737, o acesso à Colónia pela campanha passou a ser 
A partir do estabelecimento do Rio Grande - assim como da importância da ilha de Santa Catarina como escala para a defesa da Colônia - a indefinição de atribuições acerca de a qual dos governos - do Rio ou de São Paulo - deveriam ficar subordinados os novos territórios, apresentava-se como um problema latente. Gomes Freire escrevia à Corte em 1737 dizia que "a parte da Capitania de S. Paulo que borda a marinha e Costa do Sul está tão falta de interesses que vivem em grande pobreza a maior parte dos seus moradores (...) que reconheci em esta guerra quanto será conveniente esteja debaixo de um só mando toda a marinha até a Colônia". ${ }^{26}$ Insistia, repetindo mais uma vez os mesmos argumentos, não apenas na preeminência do governador do Rio sobre os territórios meridionais da América portuguesa, mas inclusive conveniência da subordinação de São Paulo à sua jurisdição.

Porém, o mais incrível é que sua habilidade política e grande capacidade de negociação abrangiam a persuasão, quer do Secretário de Estado, quer de D. João V, sobre a eficácia da centralidade da jurisdição do governador do Rio de Janeiro sobre um grande e promissor território que se ramificava quer pelas marinhas e possessões no sul, incluindo São Paulo, quer pelos sertões auríferos, abrangendo Minas Gerais e os recentes descobertos em Goiás e Mato Grosso. A estratégia política de Gomes Freire iniciava-se no argumento de que: "a grande distância em que os Goyazes e Cuyabá se acham da cidade de São Paulo faz que o Governador não possa acudir as desordens que sucederem, assim me parecia que aqueles descobertos deviam ter um particular Governador e que no caso de não haver neles consignação bastante para governo independente, ficasse subordinado ao Governador das Minas Gerais e executasse as suas ordens até que o tempo ou os interesses dessem a conhecer o que melhor se podia obrar". Admitia, em seguida que, para Goiás, se nomeasse um governador, "oficial de grande fidelidade e desinteresse" que, por ser fácil o recurso a Vila Rica, "poderia executar as ordens do general das Minas Gerais enquanto um ou mais anos dava lugar a escolher-se o que fosse mais conveniente ao serviço de Sua Majestade". Sugeria, portanto, que o governo de Goiás fosse subordinado ao governador das Minas, ou seja, a ele próprio. ${ }^{27}$

controlado pelos espanhóis. No que diz respeito ao Rio Grande, Cristóvão Pereira de Abreu, homem de negócios da Colónia, comerciante de couros, abriria, em 1732, o caminho terrestre ligando o Rio Grande a Curitiba, Sorocaba e a região das Minas. Heloísa Bellotto afirma que, pelos anos de 1730, Cristóvão Pereira Abreu começou a trazer não só muares, como também cavalos arrebanhados no Prata pela rota do Viamão. Após 1750, a rota mais comum era 0 caminho aberto entre Rio Grande e São Paulo, que passava por Santo António da Patrulha, São Francisco de Paula, Campos da Vacaria, Lages, Campos Gerais, Itararé e Sorocaba. Antes, porém, de acordo com a mesma autora, eram utilizados caminhos parciais, como a Estrada do Convento, aberta em 1727. Tropas saíam de Viamão em Setembro e Outubro e chegavam a Sorocaba em Janeiro, Fevereiro ou Março. Pagavam no registro de Curitiba direitos que tinham sido estabelecidos em 1747, e arrematados por meio de contratos, na Corte, a partir de 1752. Cf PRADO, em capítulo deste dossiê; e BELLOTTO.Op.Cit., p. 29-30.

26 Apud FREIRE. Op.Cit., vol. II, p. 583.

27 Ibidem, p. 583. 
A 11 de Agosto de 1738, uma provisão régia separou a Ilha de Santa Catarina e o Rio Grande de São Pedro da jurisdição de São Paulo, unindo-os ao governo do Rio de Janeiro, para que ficassem "todos os portos e lugares da marinha debaixo de um só mando". Em Dezembro de 1740, nova resolução régia retirou Laguna da jurisdição de São Paulo, passando-a para a do Rio de Janeiro. ${ }^{28}$

A 29 de Janeiro de 1748, dez anos depois das instâncias de Gomes Freire sobre a inutilidade de um governador com patente de general em São Paulo, o Conselho Ultramarino afirmava que um governo independente só havia sido outrora necessário por ser "São Paulo o caminho e comunicação das Minas Gerais", impondo-se então que ali se nomeasse "governador que pudesse mais facilmente acudir as ditas Minas quando os negócios delas o requeressem". Naquele momento, no entanto, considerava ser "tão supérflua a assistência do Governador e Capitão General" naquela capitania, como "a reputa[va] indispensável nos distritos de Goiás e Cuiabá". ${ }^{29}$

Com a extinção, em 1748, de um governo autónomo em São Paulo, seus territórios, que se estendiam até os confins dos de Minas Gerais, Rio de Janeiro e Santa Catarina passaram a ser administrados, em termos militares, pelo governador da praça de Santos. Este, por sua vez, subordinava-se ao governador do Rio de Janeiro. ${ }^{30}$ O alvará de 9 de Maio de 1748 criou as capitanias de Goiás e de Mato Grosso, cujos territórios, desmembrados da jurisdição de São Paulo, passaram a ser governados interinamente por Gomes

28 Cf. BELLOTTO. Op.Cit., p. 25. Segundo Márcia E. Miranda, Santa Catarina desligou-se de São Paulo, ouvidas em Lisboa as ponderações de Gomes Freire. O Rio Grande de São Pedro tornouse governo anexo a Santa Catarina, tendo sido elevado à condição de capitania por Carta Régia de 9 de setembro de 1760, seguindo-se a nomeação do primeiro governador. Apenas em 19 de setembro de 1807 o Rio Grande de São Pedro foi elevado à Capitania Geral, sendo seu governo desanexado da Capitania do Rio de Janeiro, embora apenas em 1809 o primeiro governador e capitão general tenha efetivamente tomado posse do seu governo. Esta "elevação" concedeu à Capitania do Rio Grande maior autonomia e poder de decisão, diversificando sua estrutura administrativa através da criação de órgãos específicos nas áreas da Fazenda e da Justiça, assim como a multiplicação de vilas com suas respectivas câmaras. Cf. MIRANDA, Márcia E. Continente de São Pedro: administração pública no período colonial. Porto Alegre: Assembleia Legislativa do Estado do RS / Ministério Público do Estado do RS / CORAG, 2000.

29 Ibidem, p. 27.

30 A instituição de São Paulo com governo independente do Rio de Janeiro se deu com a nomeação, como seu governador, de D. Luís António de Sousa Botelho Mourão por decreto régio em 5 de Janeiro de 1765 . Heloísa Bellotto atribui a sua restauração aos conflitos no sul perda da Colónia de Sacramento em 1763, e necessidade de defesa do Rio Grande e de Santa Catarina, responsabilidades que passaram a ser partilhadas entre ambas as capitanias, Rio de Janeiro e São Paulo; mas também às "diretrizes que o governo de D. José traçara para o Brasil: defesa do território, expansão económica e fortalecimento do poder central' - extinção das donatárias, criação de vilas, transformação dos aldeamentos indígenas em vilas, e dos índios em vassalos, reforço das fronteiras e mudança da capital. Menciona ofício do Conde da Cunha, de 12 de agosto de 1764, a Francisco Xavier de Mendonça Furtado, no qual afirmava: "matéria que necessita de providência é a prejudicial impossibilidade que há para poder governar a Capitania de São Paulo o Governador do Rio de Janeiro; porque uma Capitania tão larga e tão distante desta, com habitantes excessivamente inquietos e revoltosos, em território abundante em minas de ouro e nas vizinhanças dos Castelhanos, parece que são motivos para deverem ter um bom Governador, e Capitão General como eles pretendem, e como, muitos anos houve". BELLOTTO, p. 39-40 e 43. 
Freire. A partir daquele ano, até 1752, quando D. António Rolim de Moura, primeiro governador e capitão general nomeado para o Mato Grosso, chegou àquela capitania, a jurisdição de Gomes Freire impunha-se sobre toda a extensão do centro-sul da América Portuguesa, desde a Colónia do Sacramento, passando por Rio Grande de São Pedro, Santa Catarina e São Paulo, até os limites ainda fluidos das possessões espanholas, cujas fronteiras, se é que existiam, eram representadas pelas missões do Paraguai, a sul, e pelos aldeamentos de Moxos e Chiquitos a oeste. ${ }^{31}$

\section{Terceira conjuntura: 1750-1777}

A centralidade assumida pela cidade do Rio de Janeiro, assim como a idéia de "cabeça" de um vasto território, além da experiência de um governador tão hábil política, administrativa e militarmente, podem ter influenciado a nomeação de Gomes Freire de Andrade, em 1752, como plenipotenciário que negociaria com o seu equivalente espanhol a forma de execução das disposições do Tratado de Madrid. A cidade e a capitania do Rio de Janeiro ficariam mais uma vez "acéfalas", sendo governadas durante os oito anos seguintes por governadores interinos. ${ }^{32}$

No mesmo, outra providência régia reafirmaria a centralidade e a governabilidade do Rio de Janeiro e das capitanias e territórios adjacentes. Embora criado por decisão régia de 16 de Fevereiro de 1751, instalou-se no Rio de Janeiro, em Julho de 1752, o Tribunal da Relação, com o mesmo regimento do já existente na Bahia desde meados do século anterior. Sua criação viria, em vez de enfraquecer, dilatar, em diferentes campos, a jurisdição do governador, na medida em que a ele era destinado o papel de regedor do tribunal. Apesar dos conflitos que poderiam ocorrer entre os magistrados da Relação e o governador ou, a partir de 1763, o vice-rei, o progressivo acréscimo de sua jurisdição, inclusive nos assuntos de justiça, não seria revertido. ${ }^{33}$

Em 1758 a Guerra dos Sete Anos já havia ganho a Europa, e com ela multiplicavam-se as manobras de corso em alto mar e a acirrada disputa entre Inglaterra e França em torno dos territórios ultramarinos. Embora Portugal mantivesse uma situação de neutralidade, o medo de uma invasão ao Brasil, e especificamente ao Rio de Janeiro não podia deixar de assombrar os cálculos

31 Cf. ARAÚjo, Renata K. M. de. A Urbanização do Mato Grosso no Século XVIII. Discurso e Método. vol. I. Lisboa: FCSH-UNL, 2000 (tese de doutorado inédita); JESUS, Nauk Maria de. Na Trama dos Conflitos. A administração na fronteira oeste da América portuguesa (1719-1778). Niterói: PPGH-UFF, 2006 (tese de doutorado inédita).

32 A 18 de fevereiro de 1752, ao partir para o Sul, Gomes Freire deixou no governo interino do Rio de Janeiro Matias Coelho de Sousa que, morrendo em 1753, foi substituído pelo mestre de campo Patrício Manuel de Figueiredo até 1753 . Em vista disso, uma carta régia de 16 de maio de 1753 nomeou José António Freire de Andrade governador interino do Rio de Janeiro. Em suas constantes viagens às Minas, o mestre de campo assumia o governo provisório da cidade. 33 WEHLING, Arno; Wehling, Maria José. Direito e Justiça no Brasil Colonial. O Tribunal da Relação do Rio de Janeiro (1751-1808). Rio de Janeiro: Renovar, 2004. 
políticos da corte de Lisboa. As suspeitas tornaram-se ainda mais justificadas quando os ministros lisboetas receberam notícias de que, a 23 de julho de 1757 , entraram na barra do Rio de Janeiro seis navios franceses, transportando três regimentos de desembarque, 36 companhias de Infantaria e Dragões e um general de terra. Os relatos e a documentação referentes àquela arribada descreviam com cores quentes o "terror pânico" que invadiu e assolou o Rio de Janeiro durante a permanência da esquadra francesa no porto. ${ }^{34}$ Gomes Freire encontrava-se no sul, tendo sido substituído no governo interino José Antônio Freire de Andrade. Este, achava-se em Minas, onde fora tratar da arrecadação dos tributos régios. Deixara em seu lugar o tenente coronel Patrício Manoel Figueiredo, homem inexperiente, como visivelmente demonstrara sua ação titubeante diante da ameaça representada pela expedição francesa.

A significação desse episódio para a reorientação da política régia em relação aos domínios ultramarinos foi incalculável. Ele nos fornece a chave de entendimento de uma série de fatos que se sucederam e que indicam a adoção de uma nova estratégia de governo e de prioridades em relação ao Brasil, e mais especificamente ao Rio de Janeiro.

Uma Memória redigida pelo Conde de Oeiras, baseada em três consultas do Conselho Ultramarino, mencionava o "conhecimento que os referidos Franceses conseguiram pela inspeção ocular, que Ihes manifestou 0 absoluto e deplorável desamparo em que viram o Rio de Janeiro, sem Governador capaz de animar os Povos com o respeito de sua pessoa e com a fé da sua ciência militar (...)."35 Prudente, ponderava entre duas alternativas: "ou de se abandonar o preciosíssimo Empório do Rio de Janeiro, e com ele todo o Estado do Brasil aos insultos da cobiça e da necessidade dos Franceses, ou de se suspenderem as operações da Campanha do Uruguai, com o perigo de se queixarem por isso os Espanhóis". Pareceu-lhe, "sem hesitação", que "o segundo destes dois males se devia eleger como incomparavelmente menor". ${ }^{36}$

A argumentação de Oeiras é enfática: a perda do Rio de Janeiro significava a perda do Brasil, e portanto da moeda de garantia que Portugal dispunha para se sustentar na intrincada rede dos conflitos em torno da hegemonia européia durante o século XVIII. Sob os auspícios de Carvalho e Melo fora enviado, em outubro de 1758, um ofício ao Chanceler da Relação do Rio de Janeiro, ordenando-Ihe que sugerisse às câmaras de todas as vilas e cidade daquela capitania que escrevessem a Gomes Freire, pedindo-lhe que voltasse imediatamente ao Rio, por ficarem seus moradores, na sua ausência, indefesos diante da incessante "audácia" dos franceses, lembrando-lhe ainda

34 A expedição do Conde de Aché é amplamente documentada. No que diz respeito à correspondência das autoridades coloniais entre si, com o Capitão da Esquadra francesa e com Lisboa, ver AHU, RJ, Cat. C. A., docs. 20.320 a 20.326, 20. 338 a 20.368, e ainda RJ, Avulsos, Cx. 62, docs. 38 e 62; Cx. 63, doc. 23 e Cx. 64, doc. 75. Pela parte da França, no que diz respeito à preparação da esquadra e ao sucesso de sua missão, ver CARAN, Marine, B4, 77. Cf. BICALHO. A Cidade e o Império. Op.Cit. p. 60-69.

35 No AHU encontram-se três cópias desta memória: AHU, RJ, Avulsos, Cx. 64, doc 75; Cx. 65, doc. 25; e Cód. 565.

36 Idem. 
que "não podia negar o socorro havendo jurado a homenagem de os defender, e sustentar". 37

No entanto, durante a Guerra dos Sete Anos, a ameaça mais concreta de uma invasão que a América portuguesa provou não era proveniente dos súditos do Rei da França, mas sim dos castelhanos de Buenos Aires. Seu objetivo não era o Rio de Janeiro, mas as praças e territórios meridionais. Inconformado com o fracasso das disposições do Tratado de Madri e com a relutância dos portugueses em abandonarem a Colônia do Sacramento, D. Pedro de Cevallos, governador de Buenos Aires, planejou um ataque aos fortes portugueses naquela região com a finalidade de expulsá-los não só da Colônia, mas também do Rio Grande e de Santa Catarina. ${ }^{38}$ Em agosto de 1762 transportou homens para as cercanias da Colônia. Em outubro recebera avisos de Madrid comunicando ter a Espanha declarado guerra a Portugal. Iniciou imediatamente 0 ataque e, 25 dias depois, tomou a cidadela, expulsando os portugueses.

Não satisfeito com as vitórias conquistadas até então, e fortemente determinado em expulsar os portugueses de todo aquele território, o governador de Buenos Aires armou, em abril de 1763, cerca de 1.000 homens, conduzindo-os pelo litoral até as muralhas das fortalezas de Santa Teresa e São Miguel, a sul da Lagoa Mirim. Nova vitória dos castelhanos, desta vez sem grandes esforços de guerra e sem muitas perdas. Os portugueses que guarneciam as fortificações, amedrontados diante da visão das tropas inimigas, sem poder avaliar bem o seu número, entraram em pânico, abandonando Santa Teresa, conseguindo alguns, refúgio em São Miguel, onde disseminaram-se boatos da grande superioridade dos espanhóis. Tais notícias fizeram com que 0 comandante e sua guarnição se rendessem antes mesmo de uma primeira batalha. As tropas castelhanas tinham caminho aberto para a vila do Rio Grande, onde de fato entraram a 24 de abril de 1763, achando-a vazia, uma vez que os homens encarregados de sua defesa haviam igualmente desertado. Rumavam já os espanhóis para Viamão, quando receberam notícias da suspensão das rivalidades entre as respectivas coroas. Tanto em Fontainebleau, quanto em Paris, os tratados que puzeram termo à Guerra dos Sete Anos foram assinados sem conhecimento das manobras no sul da América, porém ambos incluíam cláusulas preconizando restituições territoriais mútuas. ${ }^{39}$

Foi nesse contexto político internacional que se deu a transferência da Capital do Estado do Brasil para o Rio de Janeiro. Embora a cidade viesse passando por grandes transformações durante toda a primeira metade do

37 AHU, Códices 565, N. 14, e 565, N. 15. Cf. BICALHO, A Cidade e o Império.... Op.Cit., p. 6769; ALDEN. Op.Cit., p. 93.

38 Dauril Alden afirma que Cevallos chegara a projetar uma invasão ao Rio de Janeiro, mas voltou atrás diante da consideração de que para tanto seriam necessários por volta de 7.000 a 8.000 homens, força que nem ele, nem a Espanha - envolta com a guerra continental dispunham no momento. Considerou que o referido ataque deveria ser feito por alguma potência aliada, como por exemplo a França, enquanto aos espanhóis caberia concentrar seus esforços no Sul. Cf. ALDEN. Op.Cit., p. 94, nota 52.

39 Sobre os embates no sul, cf. ALDEN. Op.Cit., p. 96-104. 
século XVIII, apenas em 1763 tornar-se-ia sede do vice-reinado. A documentação sobre essa decisão por parte da metrópole é escassa e pouco eloqüente quanto às razões que a forjaram. Em 16 de abril de 1761, uma carta régia ordenava a Gomes Freire que passasse à Bahia e tomasse posse do governo do Estado. Em resposta, o então Conde de Bobadela julgava que abandonar o governo do Rio "sem cabeça, me faz grande dificuldade", por ser ela "o manancial de que pende e se fortifica a conservação do Reino e das Conquistas." ${ }^{\prime 40}$

E no Rio de Janeiro Gomes Freire ficou até que, em janeiro de 1763, faleceu após uma rápida, mas fulminante doença. No dia 7 daquele mês o Bispo do Rio de Janeiro escrevia a Francisco Xavier de Mendonça Furtado, atribuindo a causa da sua morte à perda da Colônia do Sacramento. A 11 de maio do mesmo ano, nova carta régia nomeava $D$. António Álvares da Cunha vice-rei do Estado do Brasil, ordenando-lhe que passasse a residir na cidade do Rio de Janeiro. A 21 de dezembro o Conde da Cunha comunicava ter tomado posse daquele governo. ${ }^{41}$

Para compreendermos a centralidade do Rio de Janeiro como sede do vice-reinado é necessário voltar ao último regimento conferido, no reinado de D. Pedro II, aos governadores do Estado do Brasil, datado de 23 de janeiro de 1677. Embora passados quase dois séculos, e apesar das profundas mudanças políticas e económicas decorrentes de uma nova conjuntura internacional e da dimensão territorial e administrativa assumida pela América portuguesa, a patente do Conde da Cunha, ao tomar posse do governo do Rio de Janeiro, com título de vice-rei, deveria seguir o mesmo regimento, enquanto não se determinasse o contrário.

Em inícios do século XIX, D. Fernando José de Portugal, então vice-rei e capitão general de mar e terra do Estado do Brasil foi encarregado de apontar as ordens que ao longo daqueles 200 anos haviam alterado, ampliado ou restringido as jurisdições do governante mor do Estado do Brasil. É curioso notar que sua primeira observação foi ter encontrado nos livros da secretaria do governo do Rio de Janeiro, além do último regimento, de Roque da Costa Barreto, de 1677, o conferido, em janeiro de 1679, a D. Manuel Lobo; que, por ser então somente governador do Rio, não seria por ele comentado. ${ }^{42}$

Quanto ao documento que definia as atribuições dos governadoresgerais, e então vice-reis, a primeira providência, ao ser-lhes entregue 0 governo, era a inspeção das fortalezas, armazéns e tercenas, o que remete ao

40 AHU, RJ, Avulsos, Cx. 70, doc. 40. Ofício do Conde de Bobadela para o Conde de Oeiras, expondo os motivos que o impediam de cumprir a ordem régia relativa à sua transferência para a Bahia. Rio, 12 de abril de 1762.

41 AHU, RJ, Avulsos, Cx. 76, doc. 43. Ofício do Conde da Cunha, de 21 de dezembro de 1763. 42 "Regimento que trouxe Roque da Costa Barreto, mestre de campo general do Estado do Brasil em data de 23 de Janeiro de 1677 com várias observações feitas pelo actual vice-rei, e capitão de mar, e terra do Estado do Brasil, D. Fernando José de Portugal, em cumprimento da Provisão do Conselho Ultramarino de 30 de Janeiro de 1796 cuja execução se recomenda por outra de 10 de Abril de $1804 \mathrm{em}$ as quais se apontam as ordens que tem alterado, ampliado ou restringido alguns capítulos do mesmo regimento, interpondo-se o parecer sobre os artigos presentemente praticáveis". In Documentos Históricos da Biblioteca Nacional, vol. 6. Rio de Janeiro: Augusto Porto \& Cia, pp. 312-459. 
caráter essencialmente militar do cargo. Nos três primeiros anos de seu governo, Sebastião de Carvalho e Melo transmitiu ao Conde da Cunha a recomendação régia para que dedicasse especial cuidado ao reparo das fortificações e à organização das forças de defesa da capital. No entanto, considerando que a guarnição nela existente não era tão numerosa a ponto de poder resistir a um ataque estrangeiro, D. José I resolvera, em 1766, estabelecer no Rio um corpo de tropas regulares, composto dos regimentos provenientes de Moura, Bragança e Estremoz. ${ }^{43}$ Decidira encarregar também 0 tenente general austríaco João Henrique Böhn da inspeção geral de todas as tropas do Estado do Brasil - para que "todas elas constituam um só e único exército debaixo das mesmas regras e da mesma idêntica disciplina" -; e o brigadeiro e engenheiro militar sueco Jacques Funck, da responsabilidade pelo projeto, reparo e construção das fortificações. ${ }^{44}$

Seguia-se o compromisso com a conversão das "gentes do Brasil" ao catolicismo. Mudanças significativas haviam sido introduzidas com a expulsão da Companhia de Jesus e a anterior promulgação, em maio de 1757 , do Diretório dos Índios. Embora concebido inicialmente para as povoações indígenas do Pará e Maranhão, o Diretório teve ampla execução. Cabia ao vicerei conferir patentes, sem submetê-las à confirmação régia, ao capitão-mor, sargento-mor, capitães e alferes, escolhidos entre os próprios índios, em cada uma das vilas e aldeias de sua área de jurisdição. Esta, além das cinco aldeias existentes na capitania do Rio de Janeiro, incluía os aldeamentos de São Lourenço e de Nossa Senhora dos Anjos, no continente do Rio Grande.

De acordo com o capítulo 70 do regimento dos governadores-gerais, as serventias dos ofícios de justiça, guerra e fazenda, quando não eram dadas pelo rei, proviam-nas os governadores-gerais e vice-reis do Estado do Brasil, embora não Ihes fosse permitido criar novos ofícios, e constituir-Ihes ordenados sobre a Fazenda Real, ou acrescentar os valores daqueles já existentes. Notese, no entanto, que cabia ao vice-rei prover apenas os ofícios na capitania do Rio de Janeiro e naquelas que Ihe continuavam subordinadas, pois, de acordo com a observação relativa ao capítulo 38, sobre o mesmo tema, "há muitos anos que não provê os que vagam nas outras capitanias". ${ }^{45} \mathrm{Ou}$, como afirma Dauril Alden, em seu estudo sobre a administração Marquês do Lavradio (1769-

43 A carta régia que determinou o envio dos três Regimentos é datada de 30 de junho de 1766. Anais da Biblioteca Nacional do Rio de Janeiro, vol. XXXII, p. 280-281.

44 Os capítulos $15^{\circ}$ e $16^{\circ}$ do regimento dos governadores gerais e então vice-reis tratam das Ordenanças e das Tropas Auxiliares, assim como da forma de provimento e hierarquia de seus oficiais. "Regimento que trouxe Roque da Costa Barreto.... Op.Cit., p. 340-349.

45 Segundo D. Fernando José de Portugal, apenas por decreto de 16 de Fevereiro de 1799, em função das dúvidas suscitadas entre os governadores e as Juntas da Fazenda das capitanias de ultramar, D. Maria (ou, na altura, o príncipe regente) decidiu que às Juntas ficassem pertencendo as nomeações de todos os ofícios da fazenda de suas respectivas repartições, sendo os provimentos assinados pelos governadores, como presidentes delas, ficando porém as propriedades ou serventias vitalícias reservadas "à mesma Senhora para as conferir, ou por decretos, ou em resolução de consultas de tribunais". "Regimento que trouxe Roque da Costa Barreto...Op.Cit., p. 327-332 e 396. 
1779), a jurisdição dos vice-reis na segunda metade do século XVIII não se estendia além da circunscrição da capitania na qual residiam. ${ }^{46}$

Sobre as questões atinentes à Fazenda Real, os comentários de D. Fernando José de Portugal esclarecem que o vice-rei e os demais governadores eram presidentes das Juntas da Fazenda que se criaram nas diversas capitanias do Brasil, sujeitas imediatamente ao Erário Régio. O ofício de provedor mor da fazenda foi extinto, na Bahia, por alvará de 3 de Março de 1770. Embora também fosse abolido no Rio de Janeiro, não o foi em Santa Catarina, ficando o provedor da fazenda subordinado à Junta daquela capitania. ${ }^{47}$ Apesar da limitação de seus poderes sobre as demais capitanias que não lhe eram imediatamente subordinadas, o fato de o vice-rei, para além de sua alargada jurisdição militar, ocupar o cargo de presidente da Junta da Fazenda e do Tribunal da Relação, conferia-Ihe posição arbitral nas mais importantes matérias relativas ao ultramar.

No que diz respeito à centralidade do Rio de Janeiro em relação à região meridional do Brasil, e voltando à década de 1760 e às incursões castelhanas às fortificações e vilas portuguesas, as disputas entre as duas coroas na região ficavam cada vez mais tensas e acirradas. Na Europa, a diplomacia não chegou a um acordo que substituísse o fracassado Tratado de Madrid. Em fevereiro de 1761 foi assinado em El Pardo, o tratado que revogou definitivamente o acordo de 1750.

Em fins de Março de 1776, tropas portuguesas capitaneadas pelo general Böhn e o pelo capitão de mar Mac-Dowall tomaram o Rio Grande dos espanhóis. Dauril Alden afirma que um ano antes discutia-se em Madrid sobre a possibilidade de um ataque ao Brasil. O objectivo era a conquista da Ilha de Santa Catarina e a posterior destruição da Colónia do Sacramento. O assédio a Santa Catarina, de crucial importância militar e diplomática, cortaria qualquer comunicação dos portugueses com o sul, além de facilitar a captura da Colónia e a retomada do Rio Grande, forçando Portugal a abandonar suas possessões meridionais, a ponto de seus limites retornarem ao que dispunha o Tratado de Tordesilhas. O plano se concluiria com a criação do Vice-Reino do Prata, tendo como primeiro Vice-Rei D. Pedro de Cevallos. ${ }^{48} \mathrm{~A}$ armada espanhola composta de 116 embarcações, 20 das quais eram navios de guerra, 10.000 soldados,

46 ALDEN. Op.Cit., p. 30.

47 Segundo Márcia E. Miranda, a Provedoria Real do Rio Grande de São Pedro foi criada em 11 de Setembro de 1748, que ordenava também o estabelecimento de provedorias na Colónia do Sacramento e em Santa Catarina. O cargo de Provedor da Fazenda Real no Rio Grande foi, no entanto, provido por decreto régio de 19 de Novembro de 1749. A partir de 1766 o provedor deveria enviar suas contas à Contadoria Geral da Junta da Fazenda Real do Rio de Janeiro. Por ordem de 2 de Dezembro de 1774, deste tribunal, criou-se a Junta da Real Fazenda do Rio Grande de São Pedro. Nova provisão régia determinou sua abolição em $1^{\circ}$ de Janeiro de 1780 , substituindo-a pela Provedoria da Fazenda, com as funções e oficiais que detinha antes da criação da Junta. Por provisão de 24 de Setembro de 1798, a rainha ordenava a extinção das provedorias do Rio Grande e de Santa Catarina, novamente criadas pouco tempo depois. Sua abolição definitiva era determinada por carta régia de 14 de Junho de 1802, que também ordenava a criação da Junta da Administração da Real Fazenda do Rio Grande de São Pedro. MIRANDA. Op.Cit., p. 91-94.

48 ALDEN. Op.Cit., p. 196-197. O Vice-Reino do Prata foi criado em 1796. 
8.500 marinheiros e 500 "maestranza" - com mantimentos para seis meses de campanha - pôs-se ao mar em meados de Novembro.

Em Lisboa, as notícias da expedição inimiga levantaram inúmeras suposições quanto aos seus possíveis alvos na América. Num primeiro momento parecia lógico um ataque visando a reconquista do Rio Grande, para o qual Böhn fora alertado. ${ }^{49}$ Mas, pouco depois, Carvalho e Mello fora advertido pelo embaixador português em Madrid de que fontes seguras lhe informaram que os espanhóis pretendiam antes abordar algum porto das capitanias do norte. As atenções metropolitanas voltaram-se então para Bahia, cujas defesas estavam enfraquecidas. O Marquês de Lavradio, então vice-rei, enviou o brigadeiro José Custódio de Sá e Faria, com reforços, para a cidade de Salvador. ${ }^{50}$ Ao mesmo tempo, tratou de aprimorar as defesas da própria capital. ${ }^{51}$

Entretanto, as últimas informações chegadas à corte portuguesa especificavam que o intento dos espanhóis não era atacar a Bahia, nem mesmo o Rio de Janeiro. A partir de Setembro de 1776, as ordens emanadas de Lisboa direcionaram-se para o municionamento e defesa das praças do sul. ${ }^{52}$ Apesar dos preparativos de última hora, a força naval luso-brasileira sob o comando do capitão de mar Roberto Mac Dowall era insignificante se comparada à esquadra

49 AHU, RJ, Avulsos, Cx. 110. doc. 68. Cartas de Martinho de Mello e Castro ao Marquês do Lavradio, a primeira de 6 de Agosto de 1776; e a segunda, de 21 de Agosto de 1776.

50 Biblioteca Nacional do Rio de Janeiro (BNRJ), Seção de Manuscritos (Mss), I-31,31,1, N. 4.

51 Lavradio escreveu, em outubro de 1776, a D. Antônio de Noronha, então governador das Minas, pedindo-Ihe que enviasse o Regimento de Cavalaria que acabara de formar naquela Capitania, e ainda algumas tropas de Auxiliares, para ajudarem na defesa do Rio de Janeiro. Em resposta, D. Antônio informava que ia remetendo os Oficiais e soldados da Cavalaria que se encontravam prontos no quartel de Vila Rica, salvo aqueles necessários para as "diligências precisas". Quanto a recrutar Auxiliares e Ordenanças, dizia ser impossível fazê-lo sem que se seguissem grandes inconvenientes, "porque os homens brancos desta Capitania são muito poucos a respeito dos negros e mulatos", e, caso os recolhesse de seus distritos enviando-os ao Rio de Janeiro, "ficará esta Capitania exposta a alguma sublevação dos mesmos negros aquilombados". Lavradio não se sensibilizou com seus argumentos, e ordenou-lhe que enviasse não somente a totalidade do regimento de cavalaria, mas que formasse corpos de brancos, negros e mulatos vadios e os acompanhasse em pessoa ao Rio de Janeiro. O governador das Minas retrucou com firmeza, lembrando ao vice-rei que manter a tranquilidade e a segurança da capitania sob sua jurisdição, e promover a agricultura e a mineração, eram os primeiros objetivos do seu governo. Defendia a utilidade dos vadios naqueles sertões, por povoarem áreas remotas, protegerem as fronteiras de ataques indígenas, abrirem caminhos e estradas e participarem nas expedições de captura de negros fugidos. Quanto a acompanhar as tropas à capital, só o faria se o vice-rei nomeasse um governador interino que o substituísse no período de sua ausência. Embora tenha permanecido em Minas, D. Antônio de Noronha enviara ao Rio 241 soldados do Regimento de Cavalaria e 928 homens das Tropas Auxiliares e Companhias francas, arregimentados para aquela ocasião específica. Cf. BNRJ, Mss, 2, 2, 24, N. 17; Carta do Marquês de Lavradio a D. António de Noronha, de 28 de Outubro de 1776; 2, 2, 24, N. 18. Ordens de Lavradio citadas na resposta de D. Antônio de Noronha, de 17 de Novembro de $1776 ; 2,2$, 24, N. 31. Carta de D. Antônio de Noronha para o Marquês de Lavradio, 19 de Novembro de 1776; 2, 2, 24, N. 37. Carta de D. Anônio de Noronha para Martinho de Mello e Castro, de 7 de janeiro de 1777.

52 BNRJ, Mss, I-31, 31, 1, N. 21. Ofício de Carvalho e Mello ao Marquês de Lavradio, de 9 de setembro de 1776; BNRJ, Mss, I-31, 31, 1, N. 31. Carta de Martinho de Mello e Castro ao Marquês de Lavradio, de 11 de Setembro de 1776. 
espanhola. ${ }^{53}$ Três meses após a saída de Cádiz, a 13 de Novembro de 1776, a expedição capitaneada pelo Marquês de Casa Tilly e por D. Pedro de Cevallos chegava ao litoral de Santa Catarina, em fins de Fevereiro de 1777. Diante da grande superioridade da armada inimiga, a 20 de Fevereiro, um Conselho de Guerra convocado por Mac Dowall decidira que os navios sob seu comando deveriam retornar ao Rio de Janeiro, afim de conseguir reforços e obter novas instruções do vice-rei. Desembaraçados da oposição naval de proteção da ilha, não foi difícil para os castelhanos descerem à terra. Quando se preparavam para tomar a fortaleza de Ponta Grossa - a primeira situada na entrada da baía - os espanhóis descobriram, atônitos, que ela havia sido evacuada. O mesmo aconteceu com os fortes de Santa Cruz e Ratones, localizados mais adiante. Em 26 de Fevereiro, Cevallos ocupou a vila de Santo António, a duas léguas de Desterro, para onde enviou uma delegação exigindo sua capitulação. Em resposta, soube ter sido também aquela vila abandonada. Repetia-se, uma vez mais, em Santa Catarina, o mesmo que, em 1763, ocorrera no Rio Grande. As capitulações foram assinadas a 5 de Março de $1777 . .^{54}$

Cevallos pretendia ocupar o Rio Grande, segundo objetivo de seu plano maior de expulsar os portugueses de toda a região. No entanto, as negociações e tarefas que envolviam a capitulação de Santa Catarina - inventários das presas e dos saques, ofícios a serem remetidos a Madrid, envio dos prisioneiros ao Prata, medidas de segurança para manter as conquistas frente a uma possível investida lusa - o detiveram mais do que previra naquela ilha. Quando zarpou rumo ao sul, o mau tempo e os ventos contrários impediram que alcançasse o litoral do Rio Grande, obrigando-o a ir diretamente ao estuário platino, onde entrou no porto de Maldonado no dia 18 de Abril. Dali preparouse para conquistar e destruir definitivamente a Colônia do Sacramento, que já vinha sofrendo havia alguns meses um duro bloqueio de forças espanholas enviadas pelo governador de Buenos Aires. Não foi difícil, nestas circunstâncias, a capitulação da fortaleza. A 4 de Junho de 1777, forças espanholas conquistavam a Colônia do Sacramento pela quarta vez nos noventa e sete anos de sua existência. Nos dias que se seguiram, a cidadela fora completamente destruída.

Enquanto os portugueses perdiam para os espanhóis algumas de suas principais possessões na América meridional, sofriam um outro tipo de perda, desta vez em seu próprio território. Com o falecimento de D. José I, D. Maria herdava o trono. Uma de suas primeiras decisões fora a demissão do Marquês de Pombal. Antes mesmo das notícias da queda de Santa Catarina e da Colônia chegarem à Europa, o afastamento dos dois grandes protagonistas ibéricos das intransigentes e quase sempre belicosas disputas territoriais no continente americano - Pombal e Grimaldi - levava enfim a uma acomodação que tornaria possível uma trégua.

53 ALDEN. Op.Cit, p. 217, nota 94; e p. 228, nota 15: 4 náus, 4 fragatas e 4 corvetas. Cf. ainda AHU, RJ, Avulsos, Cx. 114, doc. 15. "Mapas das Embarcações e dos seus Comandantes que compõem a Esquadra debaixo do comando do Marquês de Lavradio, de que é chefe Roberto Mac Dowell".

54 ALDEN. Op.Cit., p. 224-246. 
As negociações diplomáticas se estenderam até $1^{\circ}$ de Outubro de 1777, quando finalmente foi assinado o Tratado de Santo Idelfonso, de acordo com o qual caberia à Espanha a área da Colônia do Sacramento, embora Portugal continuasse a manter o Rio Grande e toda a região das lagoas Mirim e dos Patos, até Santa Catarina.

\section{Considerações finais}

Pretendeu-se, neste artigo, chamar a atenção para a posição central ocupada pela capitania do Rio de Janeiro na territorialização de uma imensa área da América que se encontrava ainda por ser efetivamente ocupada pelos portugueses. Como se afirmou acima, tanto as informações que a viabilizaram, quanto os recursos humanos e materiais que tornaram possível sua realização, foram disponibilizados por grupos do recôncavo da Guanabara, interessados e envolvidos num investimento político e econômico de grandes dimensões.

O desenvolvimento desse processo acabou por definir dinâmicas muito particulares, ligadas à sedimentação de interesses de grupos sociais que se enraizavam nas diferentes áreas que configuravam, pouco a pouco, a grande região centro-sul do Brasil. As conjunturas da fundação da Colônia de Sacramento; a expansão aurífera nos sertões das Gerais, seguida pelas três décadas da gestão governativa de Gomes Freire de Andrade; a subsequente transferência da capital do Estado do Brasil da Bahia para o Rio de Janeiro; os tratados diplomáticos entre Portugal e Castela para demarcação das fronteiras sul de seus respectivos domínios americanos, assim como as frequentes situações de guerra intimamente associadas aos mesmos, acabaram por definir contextos muito particulares no avanço da construção política do território da América portuguesa em seu extremo meridional. 